\title{
CAMBODIAN TWELFTH GRADERS' CHOICE FOR ENGLISH PRIVATE TUTORING: QUIT OR NOT TO QUIT?
}

\author{
Sopha Soeung \\ (soskhmer@gmail.com) \\ Hiroshima University \\ 1-5-1 Kagamiyama, Higashi-Hiroshima, 739-8529, Japan
}

\begin{abstract}
Private tutoring is not a new phenomenon for education in both developed and developing countries. However, English private tutoring (EPT) attracted a limited number of studies, although English is viewed as the key to success in non-English speaking countries like Cambodia. By observing EPT as a choice, this mixed-method study, using the convergent design, aimed to explore factors affecting Cambodian $12^{\text {th }}$ graders towards quitting or not quitting EPT during the year of the national examination. Quantitative data were collected from 639 twelfth graders in Cambodia via a self-rated questionnaire, while qualitative data were obtained from 8 respondents. Findings reveal that the decision of leaving EPT is more influenced by their parents, while that of continuing EPT is stirred by educational aspirations, internal motivation as well as part-time employment during their university life. Surprisingly, unlike private tutoring of other core exam subjects, this study found that students from better income families in Cambodia do not seem interested in investing in EPT. It is proposed that an 'exam-career balance' syllabus be developed and implemented in both mainstream schools and EPT classes to boost the success probability of Cambodian $12^{\text {th }}$ graders in their exams as well as their future.
\end{abstract}

Keywords: Cambodia, extra lesson, shadow education, private tuition

DOI: http://dx.doi.org/10.15639/teflinjournal.v31i2/322-341

After English had been banned to study since an overthrow of Pol Pot regime in 1979, it was officially introduced in the Cambodian national curriculum of lower and upper secondary school $\left(7^{\text {th }}\right.$ to $12^{\text {th }}$ grade) in 1990 (Neau, 2003). Later in 2006, English became one of the seven national exam subjects for $12^{\text {th }}$ 
graders (MoEYS, 2005). Since its start, English does not function as the core exam subjects. Yet, in Cambodia, English is viewed as being vital towards securing academic and career growth and opportunity to study abroad (Chan, 2018; Igawa, 2010). At the upper secondary school level, Cambodian students are called to take six core subjects, namely Mathematics, Physics, Chemistry, Biology, Khmer literature and composition, and History. English and French languages are electives. The passing score of both electives is 25 out of 50 . However, in the event, students score more than 25 , the difference of marks (scores from 26 to 50), referred to as the surplus-value. This value is added to the total score of the other six core subjects and divided by the number of core subjects only for the final result according to the MoEYS guideline ${ }^{1}$.

English became the most popular language in Cambodia due to two fundamental political reasons such as the presence of the United Nations Transitional Authority and Cambodia's admission to be a member of the Association of Southeast Asian Nations (Clayton, 2007). Also, it is one of the popular subjects for private tutoring (PT), which takes place before or after school hours. However, there are conflicting views among the $12^{\text {th }}$ graders and their parents on whether to take English private tutoring (EPT) or invest that time on other core subjects. Therefore, this study was designed to explore determinants affecting the Cambodian 12th graders' decision to take or not to take EPT during the year of the national examination. Additionally, the findings from this study can help unveil any effective English teaching practices; this is crucial for both policymakers and English syllabus developers in their endeavor towards improving English teaching and learning practices.

PT is not a new phenomenon for education in both developed and developing countries. Although it cannot be clearly dated when it existed, Bray et al. (2015) assumed that PT might have appeared as soon as the schooling system started. Like in some countries of former Soviet Union, PT started in

\footnotetext{
1 The Ministry of Education Youth and Sport (MoEYS) releases the guideline in Khmer language on 'school-based exam calendar and process' and 'national exam process' once every new academic year to all schools in the country. Important dates, how to design exam paper, duration per exam subject, total score and how to calculate, ... are clearly explained in these documents. From year to year, the information on the English score remains the same. The latest guidelines are school-based exam calendar and process (p.3), No. 51 moeys.s.ch.n, dated November 21, 2019; national exam process guideline (p.5), No. 10 moeys.s.ch.n, dated on February 25, 2019.
} 
Cambodia in the 1990s after the end of the Socialist system (Bray, 1999; William \& Silova, 2014). In Cambodia, the demand for PT, a strong commitment to realizing the global goal of Education for All (EFA), as well as teachers' low payment, might be the cause of PT (see William \& Silova, 2014). However, it is unwise to say that PT exists only owing to attempting to realize the EFA goal, which led to the construction of more schools and the Cambodian government's inability to supply enough qualified teachers (Bray, 2008). To tackle the lack of qualified teachers, the Cambodian Ministry of Education, Youth and Sport (MoEYS) increased the teacher-student ratio and implemented a two-shift schooling model (William \& Silova, 2014). This policy could deal with only the quantity but is unable to ensure the quality. This led to a feeling of insecurity in both students and parents to succeed in the examination. Thus, many high-income families decided to financially invest in PT (Dang, 2013; Kwok, 2010). The middle and low-income households were also influenced by their peers to invest in PT (Bray, 2010; 2013). Regardless of the level of household income, PT is a norm not only in Cambodia but also in many other contexts such as South Korea, Bangladesh, Sri Lanka, Taiwan, India, and Thailand (see Bray \& Kwo, 2014). Thus, in addition to viewing PT from a social inequality perspective, this paper also attempted to evaluate whether PT is a choice of individuals, mainly in the case of EPT in Cambodia. Huang (2017) stated that there are limited number of EPT studies, and it is worth highlighting that no prior research on EPT has been conducted in Cambodia. However, the same can be seen in some contexts such as Bangladesh, Hong Kong, and Taiwan. Still, very few of those scholarly works have attempted to investigate the factors influencing the individuals' decision on whether or not to take EPT.

English is seen as a vital language in non-native English-speaking countries and thus popular among learners (Hamind, 2016). In Bangladesh, Hamid et al. (2009) found that although the effect on the achievement of EPT and non-EPT (N-EPT) students was not reliably strong enough, it was still viewed as an essential contributor towards succeeding in the examination. On the other hand, the effectiveness of EPT was significantly highlighted by Hong Kong second-year university students (Coniam, 2014) and Korean college firstyear students towards succeeding in the achievement test (Lee, 2010). As for Bangladeshi students, they were unlikely to trust the quality of the mainstream school since they felt that they would be able to perform better in examinations only with their EPT experience (Hamid et al., 2009). Chinese students felt 
bored studying English in mainstream class as they felt that their level of English was better due to EPT (Chao et al., 2014). It can be observed that both Bangladeshi and Chinese parents had similar expectations of EPT as a contributing factor towards succeeding in their children's examinations. However, more than the achievement, peer influence (Hamid et al., 2009) and parents' expectations for their children to be part of global community (Chao et al., 2014) determined their investment in EPT in both contexts. Although their studies have yielded vast contributions to EPT, Coniam (2014) and Lee (2010) tend to focus much on academic achievement rather than on motivating factors driving students to opt for EPT. Additionally, Hamid et al. (2009) showed blurred differences between EPT and N-EPT students' perceptions of EPT beyond the secondary school level. Therefore, understanding about motivating factors driving to EPT is of crucial importance to both ESL/EFL practitioners towards effectively supporting their tutees and students.

With the hope of better academic achievement, success in the national exam, and winning a seat at university, the EPT market steadily reached the attention of rural areas and low-income families in some contexts. For example, EPT became more popular in rural Bangladesh due to the poor quality of mainstream schoolteachers, where children from low-income families preferred to invest in EPT rather than their peers from better income households (Hamid et al., 2018). Like other studies in Bangladesh (i.e., Mahmud \& Bray, 2017; Mahmud \& Kenayathulla, 2018), this qualitative study further revealed that female students favored EPT more than their male friends. This, on the one hand, can be speculated that rural/poor/female students, who have had less opportunities, may have better future self-image and "... are more likely to be motivated to take action in pursuing language studies than their peers who have not articulated a desired future goal-state for themselves" (Dornyei \& Chan, 2013, p. 440) than their peers. Thus, they may do their best to succeed in not only examination but also further education as well as to secure employment. On the other hand, their counterparts who had had EPT experiences changed their mind due to some influences. The reasons for switching were not stated in these studies, and this unknown phenomenon should be investigated to draw a clear road map for future English teaching practices in both mainstream schools and EPT classes/schools.

Since English is one of the core exam subjects in those contexts, EPT is found indispensable towards fostering students' achievement in the mainstream schools as well as the national/leaving-school examination. However, Yung's 
(2015) study highlights that some students did not prefer exam-oriented EPT. They viewed EPT as not contributing much towards improving their English communication skills and thus did not show much interest in it. Usually, it is expected that some similar findings be unveiled now and then in studies focusing on EPT in countries where English is intrinsically linked to students' academic achievement. However, little is known about students' experiences and their decision to/not engage in EPT during the year of national examination in a country, like Cambodia, where English is only an elective subject. That is why, this current paper attempts to convey the interest of ESL/EFL researchers, practitioners, and syllabus writers to new insights on the predictors urging students to take EPT continuously when they are supposed to quit. This indepth understanding will help them create a productive learning environment for 'exam-career balance': that does not only prepare students to succeed in their examinations but also in their prospective careers. With an effort to examine what factors influence the Cambodian twelfth graders' decision on whether or not to take EPT, this current study endeavored to answer these questions:

1. What factors influence the twelfth graders' EPT choice?

2. What reasons urge them to exercise their choice 'quit or not to quit EPT'?

3. What are their perceptions of EPT?

\section{METHOD}

To answer the research questions, a mixed-method study, applying the convergent design (Creswell \& Plano Clark, 2017), was employed by using a self-reported questionnaire and one-to-one semi-structured interview since the information or reliable data on PT was neither documented nor obtained easily (Bray, 2013; Valerio, 2013) from other sources. A questionnaire was distributed to 639 twelfth graders (67 students were absent during the day for data collection) in four urban upper secondary schools, located in four different municipal cities which were purposively selected based on a completion rate of the 2016 national exam, due to the fact that PT is rare in rural areas (Bray, 2013; Bray \& Kwo, 2014). Then the interview was conducted with two voluntary $(\mathrm{EPT}=1 ; \mathrm{N}-\mathrm{EPT}=1)$ students from each school (eight in total). The researcher conducted the interview in the native language, Khmer. Students were interviewed after their morning school schedule around 20 to 30 minutes before their lunchtime. 
All twelfth graders who opted for English as an elective from each school were purposively chosen to be respondents. In order to minimize any disturbance on the daily learning schedule, four research assistants (RA) were invited for the data collection process. Half-Day training on questionnaire contents and how to administer a questionnaire was conducted. Questionnaire piloting was done in one different urban school to ensure that questionnaire contents were friendly and clear enough to the real samples and to give the RAs an actual practice of the data collection process. The questionnaire was translated into Khmer prior to the piloting stage. The translation and rating scales of predictors (i.e., motivations) were adjusted after piloting in order to maximize the reliability of the information.

During the data collection process, each RA was assigned to work in one or two classes to assist the respondents. In case a respondent asked a question that RAs could not answer, they had to invite the researcher to clarify. The researcher was present at the same school with his RAs and involved in the entire process. It took one fifty-minute period $\left(2^{\text {nd }}\right.$ or $3^{\text {rd }}$ period of the day) per school for this process. Then, the researcher conducted a one-to-one semistructured interview with each voluntary student separately and informally in order to prompt elaborate responses from the interviewees. The 'Gaining rapport technique' was adapted to a great extent during this interview process so as to allow the informants to talk freely and confidently without being interrupted or intimidated (see Leech, 2002). However, probing was done based on the study-related instance raised by each informant. Voice recordings and note takings were done during the interview with the samples' permission. The data were collected during the second semester of the academic year 20172018. It took ten working days for the research team to complete the entire data collection process due to the research sites which were scattered.

The survey questionnaire was divided into two main parts. The first part was designed by using a rating scale and divided into three groups of predictors (see table 1) to explore various determinants that affect the decision for EPT. In the first group of predictors in this study, the distance of their home from school was used to categorize their geographical area: suburb and urban. Purposively, if they stayed less than eight kilometers (about five miles) from school, it was referred to as urban, while further than this was termed as a suburb. According to Niu (2017), socioeconomic status (SES) was a combining result of family income, parents' education and occupation. Additionally, an estimated worth of properties like vehicles, owned home, and spared land were 
included. Eight items were composited for SES in this study $(\propto=.661)$. In the second group, motivation predictors were adapted from Zhao (2012), whereas the original five scales were changed to four to ensure reliability according to a piloting result. Four statements about teacher, materials and activities, feedback, and classroom environment were employed to measure external motivation $(\propto=.763)$ while three statements related to goal setting, expectancy and anxiety were used to measure internal one $(\propto=.621)$. The second part was a list of statements like when they quit, reasons for quitting and continuing that required participants to tick either 'agree' or 'disagree'. This part was mainly designed to ascertain reasons for their choice. Then, the interview was used to seek Cambodian twelfth graders' perceptions of learning English at regular classes and private tutoring ones. Each interview was transcribed into Khmer before transcription was sent to its owner for verification and confirmation via Telegram or Facebook messenger accordingly. Then, information was analyzed and manually coded by compositing the responses according to thematic issues.

Table 1. Descriptions of Predictors

\begin{tabular}{|c|c|c|c|}
\hline \multirow{17}{*}{$\begin{array}{l}\text { (a) dependent } \\
\text { variable } \\
\text { (b) factor analysis } \\
\text { with Varimax } \\
\text { rotation method }\end{array}$} & Variables & \multirow{2}{*}{\begin{tabular}{l}
\multicolumn{1}{c}{ Descriptions } \\
$0=$ no private tutoring \\
$1=$ take private tutoring
\end{tabular}} & \multirow{2}{*}{$\begin{array}{l}N=639 \\
(149) \\
(490)\end{array}$} \\
\hline & EPT choice ${ }^{(a)}$ & & \\
\hline & \multicolumn{3}{|l|}{ Main Predictors } \\
\hline & Gender & $\begin{array}{l}0=\text { female } \\
1=\text { male }\end{array}$ & $\begin{array}{l}(348) \\
(291)\end{array}$ \\
\hline & \multirow{2}{*}{$\begin{array}{r}\begin{array}{r}\text { Distance from home to } \\
\text { school }\end{array}\end{array}$} & $0=$ suburb & \multirow{2}{*}{$\begin{array}{l}(184) \\
(455)\end{array}$} \\
\hline & & $1=$ urban & \\
\hline & $\begin{array}{r}\text { Socioeconomic status } \\
- \text { SES }^{(b)}\end{array}$ & $\begin{array}{l}\text { Parents-related factor } \\
\text { Income-related factor } \\
\text { Fixed-assets related factor }\end{array}$ & \\
\hline & \multicolumn{3}{|l|}{ Individual Predictors } \\
\hline & \multirow{5}{*}{ Student absenteeism } & $0=$ always & (4) \\
\hline & & $1=$ almost always & (5) \\
\hline & & $2=$ sometimes & (138) \\
\hline & & $3=$ seldom & (296) \\
\hline & & $4=$ never & (196) \\
\hline & \multirow{4}{*}{$\begin{array}{r}\text { Student educational } \\
\text { aspiration }\end{array}$} & $0=$ finish high school (HS) & $(60)$ \\
\hline & & $1=$ finish $B A$ & $(320)$ \\
\hline & & $2=$ finish $\mathrm{MA}$ & (121) \\
\hline & & $3=$ pursue $\mathrm{PhD}$ & (138) \\
\hline
\end{tabular}


Soeung, Cambodian Twelfth Graders' Choice for English Private Tutoring 329

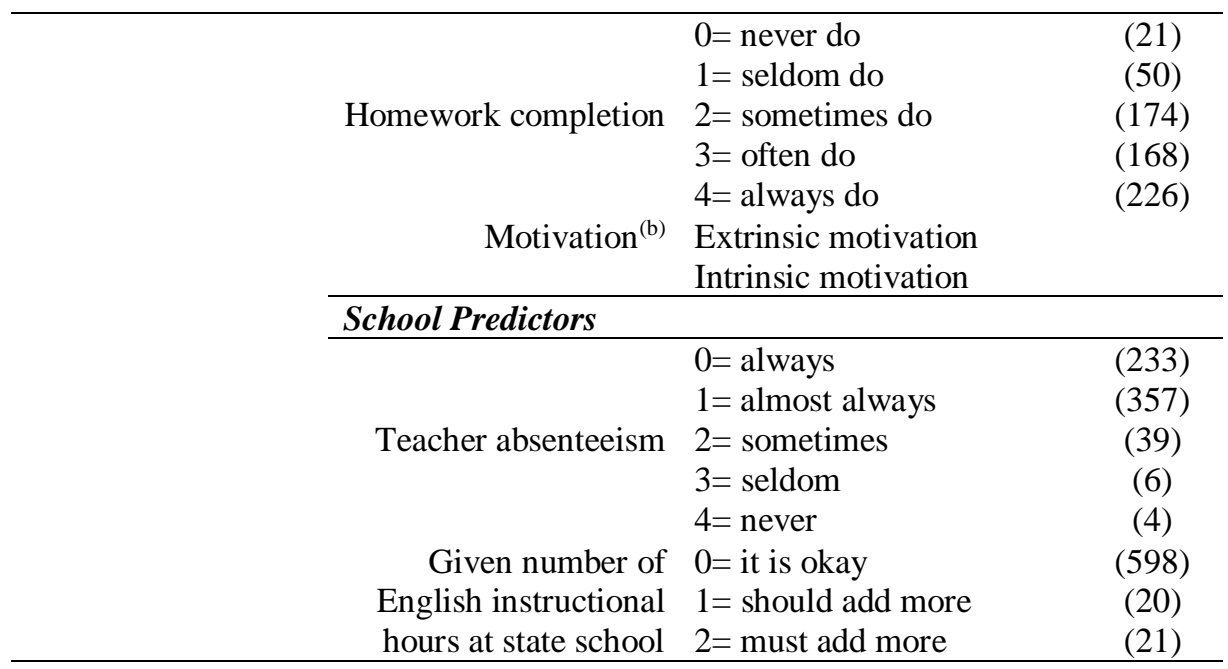

A binary logistic regression was employed for data analysis in this study due to a dummy dependent variable. Three different logistic models were applied to deeply observe the effect-level of the predictors to respond to the first research question. A descriptive analysis was used for the second question, while the third question was answered by qualitative data gathered from semistructured interviews.

\section{FINDINGS AND DISCUSSION}

The findings of each research question are first reported hereunder in a sequential manner. Then, an integration of quantitative and qualitative data is used for discussion in the last part of this section.

\section{Factors Influencing the Twelfth Graders' EPT Choice}

Results in Table 2 present factors influencing students' decision whether or not to invest in EPT during the year of the national exam. Briefly, model 1, without controlling any influencing factors, accounts for 47.7 percent of the variance in explaining, while model 2 and 3 show a modestly additional 2.1 percent and 0.2 percent respectively after controlling other factors. It can be clearly seen that predictors of model 1 have stronger influence than any predictors of individuals and schools. Therefore, the overall results indicate 
alignment with the previous findings of social inequalities of Bray and Kwo (2014), mainly in terms of gender and socioeconomic status; however, it still brings new thoughts to the field. This study unveiled similar finding to that of the other studies in Bangladesh (i.e., Hamid et al., 2018; Mahmud \& Bray, 2017; Mahmud \& Kenayathulla, 2018) where female students decided to continue EPT unlike their male counterparts. Contextually, EPT is always conducted before or after official schooling hours (e.g. 5:30-6:30 AM or 5:306:30/7:30 PM). This time might not be convenient for these female students (aged 16 to18). However, they may foresee more benefits of EPT than may their male peers. This would need more investigation. Regarding SES, students whose parents had better income preferred to quit EPT during the year of national exam. This is similar to what Hamid et al. (2018) found. On the other hand, those whose parents attained higher educational level and owned higher value fixed assets tend to go on EPT. With this in mind, it can be disclosed that SES partly influenced the decision to follow EPT. Yet, previous studies highlight that students from better income households seem to opt out of EPT and focus more on PT of other core exam subjects. In addition to the common findings, this present study revealed that students who intend to pursue tertiary education and those with higher intrinsic motivations are willing to stay on EPT. They do not limit themselves to the short-term benefits of studying English (succeed in the exam).

Table 2. Regression Coefficients of Predictors on English Private Tutoring

\begin{tabular}{lrrr}
\hline & $\begin{array}{r}\text { Model 1 } \\
\text { B (SE) }\end{array}$ & $\begin{array}{r}\text { Model 2 } \\
\text { B (SE) }\end{array}$ & $\begin{array}{r}\text { Model 3 } \\
\text { B (SE) }\end{array}$ \\
\hline Gender & $-.663(.3 .23)^{*}$ & $-.732(.344)^{*}$ & $-.753(.347)^{*}$ \\
\hline Suburb/urban & $-.043(.338)$ & $-.068(.371)$ & $-.056(.376)$ \\
\hline SES (parents-related) & $.825(.204)^{* * *}$ & $.764(.217)^{* * *}$ & $.760(.218)^{* * *}$ \\
\hline SES (income-related) & $-.969(.208)^{* * *}$ & $-.1 .370(.242)^{* * *}$ & $-1.401(.245)^{* * *}$ \\
\hline SES (fix-assets) & $4.031(.371)^{* * *}$ & $4.338(.421)^{* * *}$ & $4.406(.431)^{* * *}$ \\
\hline Student absenteeism & & $.251(.230)$ & $.251(.232)$ \\
\hline Educational aspiration & $.856(.220)^{* * *}$ & $.861(.222)^{* * *}$ \\
\hline Homework completion & $.101(.157)$ & $.075(.160)$ \\
\hline Extrinsic motivation & $-.217(.196)$ & $-.200(.198)$ \\
\hline Intrinsic motivation & $.474(.235)^{*}$ & $.477(.236)^{*}$ \\
\hline Teacher absenteeism & & & $.405(.256)$ \\
\hline $\begin{array}{l}\text { Number of instructional } \\
\text { hours }\end{array}$ & & $-.261(407)$ \\
\hline
\end{tabular}


Soeung, Cambodian Twelfth Graders' Choice for English Private Tutoring 331

Note: $\mathrm{R}^{2}$ for model $1=.477 ; \mathrm{R}^{2}$ for model $2=.498 ; \mathrm{R}^{2}$ for model $3=.500$

$* \mathrm{p}<.05, * * \mathrm{p}<.01, * * * \mathrm{p}<.001$

\section{Reasons for Quitting or Not Quitting EPT}

A descriptive response in Table 3 presents the reasons behind Cambodian twelfth graders' quitting or continuing EPT. No attempt has been made to tie EPT to either schooling system or academic achievement but to probe students' views on their future self-image. The results revealed that a large number of students (about $76 \%$ ) decided to quit EPT in $12^{\text {th }}$ grade, while about $18 \%$ had quit at an early grade. This clearly explains that the N-EPT students focused only on the core subjects for the national exam. However, it is worth highlighting that $85.71 \%$ of them realized that their English proficiency is not good enough for further education. Also, $90 \%$ stated being well aware that the surplus-value of English can contribute to upgrading their exam results. More than 55\% of the respondents admitted that quitting EPT at this grade is not their decision, while about only $44 \%$ declared being the ones to decide to quit EPT. This is aligned with the findings in the South Korean context (Prak et al., 2011) that parent(s) not only decided the PT types but also tutors for their children. However, almost all of the respondents (96.43\%) intend to resume EPT after their national exam. This can be argued that even though they need time for PT of the core exam subjects, they accept that the English language is vital for their future.

Regarding the reasons to continue EPT, $99.39 \%$ of the respondents agreed that English is good for their future study and job, while $55.1 \%$ informed that they need English to secure part-time employment to support themselves during their university. About $88 \%$ of the respondents acknowledged that their English is not good enough. Again, this result points out that the respondents showed optimism with regards to English contributing towards their future academic and career success. Similarly, about two percent higher than N-EPT students, the EPT students admitted that quitting EPT was also suggested to them by their parents, yet they decided otherwise. This can be argued that parents feel more insecure that their children might not succeed in the national exam, or they might not trust the mainstream school quality compared to their children. It would be interesting to embrace parents' attitudes and perceptions in a further study. On the one hand, $98.37 \%$ accepted that taking EPT will not impede on their preparation for the national exam; however, these respondents 
highlighted that they are aware that they need to devote some time for EPT. It is clear that the EPT group tends to give their best towards the future goal. On the other hand, it will bring more clarity if three components of future selfimage, ideal L2 self, ought-to L2 self, and L2 learning experience, suggested by Dornyei and Chan (2013, p. 438) can be evaluated in a future study.

Table 3. Descriptive Responses

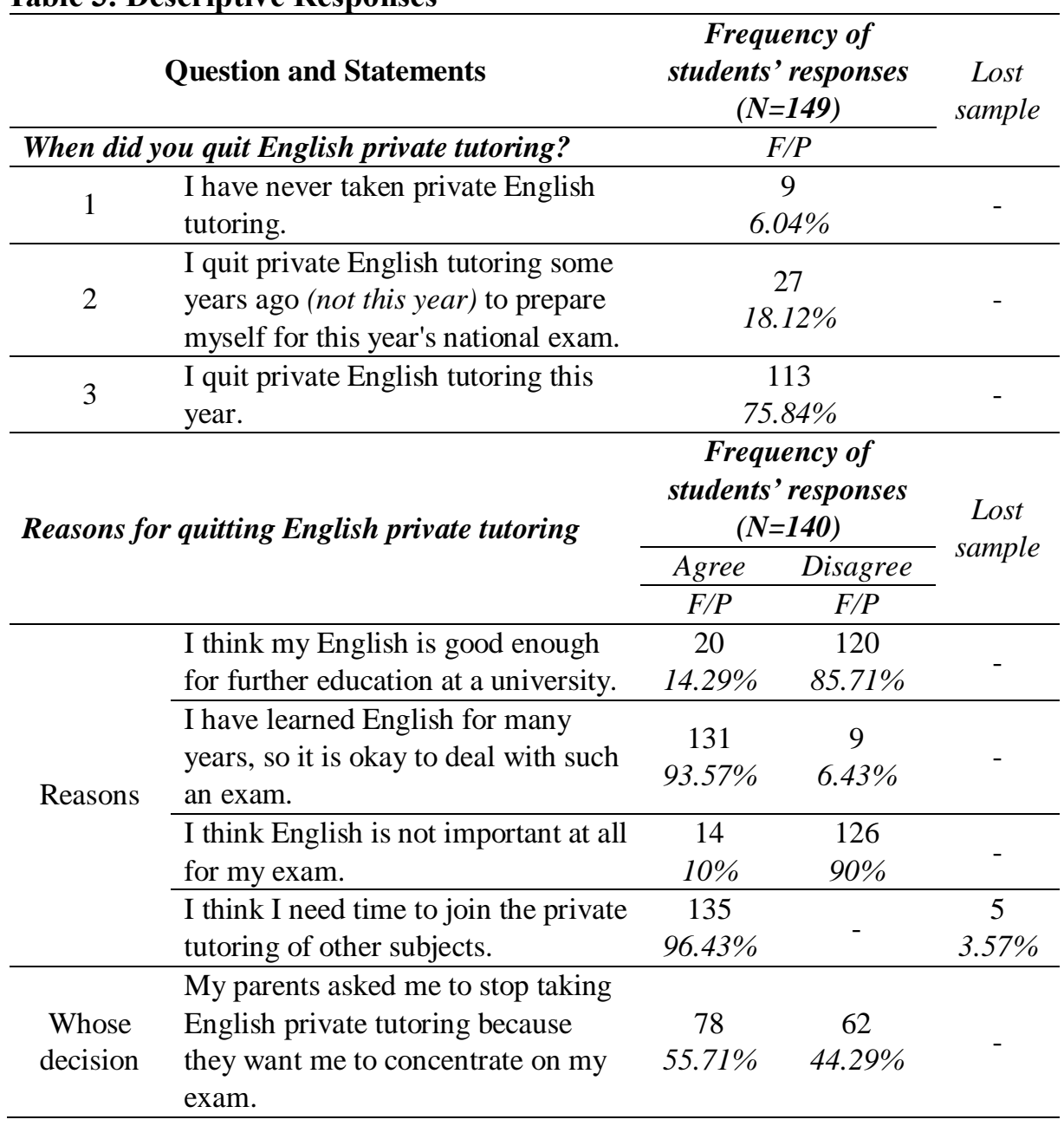


Soeung, Cambodian Twelfth Graders' Choice for English Private Tutoring 333

\begin{tabular}{|c|c|c|c|c|}
\hline $\begin{array}{l}\text { Future } \\
\text { plan }\end{array}$ & $\begin{array}{l}\text { I will continue learning English after } \\
\text { the national exam. }\end{array}$ & $\begin{array}{c}135 \\
96.43 \%\end{array}$ & $\begin{array}{c}5 \\
3.57 \%\end{array}$ & - \\
\hline \multirow{3}{*}{\multicolumn{2}{|c|}{ Reasons for continuing English private tutoring }} & \multicolumn{2}{|c|}{$\begin{array}{c}\text { Frequency of } \\
\text { students' responses } \\
(N=490)\end{array}$} & \multirow{3}{*}{$\begin{array}{c}\text { Lost } \\
\text { sample }\end{array}$} \\
\hline & & Agree & Disagree & \\
\hline & & $F / P$ & $F / P$ & \\
\hline \multirow{3}{*}{ Reasons } & $\begin{array}{l}\text { I think my English is not good } \\
\text { enough for the exam. }\end{array}$ & $\begin{array}{c}58 \\
11.84 \%\end{array}$ & $\begin{array}{c}432 \\
88.16 \%\end{array}$ & - \\
\hline & $\begin{array}{l}\text { I think English is good for my future } \\
\text { study and job. }\end{array}$ & $\begin{array}{c}487 \\
99.39 \% \\
\end{array}$ & 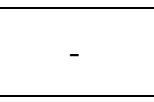 & $\begin{array}{c}3 \\
.61 \% \\
\end{array}$ \\
\hline & $\begin{array}{l}\text { I need English for a part-time job } \\
\text { because my parents cannot support } \\
\text { me. }\end{array}$ & $\begin{array}{c}270 \\
55.1 \%\end{array}$ & $\begin{array}{c}220 \\
44.9 \%\end{array}$ & - \\
\hline $\begin{array}{l}\text { Whose } \\
\text { decision }\end{array}$ & $\begin{array}{l}\text { My parents asked me to stop taking } \\
\text { English private tutoring as they want } \\
\text { me to concentrate on my exam. }\end{array}$ & $\begin{array}{c}283 \\
57.76 \%\end{array}$ & $\begin{array}{c}202 \\
41.22 \%\end{array}$ & $\begin{array}{c}5 \\
1.02 \%\end{array}$ \\
\hline \multirow{3}{*}{$\begin{array}{c}\text { Time } \\
\text { concerned }\end{array}$} & $\begin{array}{l}\text { I think taking private English } \\
\text { tutoring won't affect my time to } \\
\text { prepare myself for the national } \\
\text { exam. }\end{array}$ & $\begin{array}{c}482 \\
98.37 \%\end{array}$ & $\begin{array}{c}7 \\
1.43 \%\end{array}$ & $.20 \%$ \\
\hline & $\begin{array}{l}\text { Private English tutoring takes some } \\
\text { of my time, but I think I can manage } \\
\text { it. }\end{array}$ & $\begin{array}{c}482 \\
98.37 \%\end{array}$ & - & $\begin{array}{c}8 \\
1.63 \%\end{array}$ \\
\hline & $\begin{array}{l}\text { I just want to kill time while waiting } \\
\text { to attend the private tutoring of } \\
\text { other subjects. }\end{array}$ & $\begin{array}{c}127 \\
25.92 \%\end{array}$ & $\begin{array}{c}363 \\
74.08 \%\end{array}$ & - \\
\hline
\end{tabular}

\section{Students' Perceptions of EPT}

Bearing in mind the respondents' daily learning schedule, the researcher could interview only two voluntary respondents per school. The interviewees were in some cases selected with two main criteria: type (N-EPT or EPT) and gender in case the number of voluntary interviewees was more than the demand in one school. As a result, Table 4 presents the brief characteristics of interviewees. 
334 TEFLIN Journal, Volume 31, Number 2, July 2020

Table 4. Characteristics of Respondents

\begin{tabular}{|c|c|c|c|c|c|c|c|c|c|c|c|}
\hline \multirow[t]{2}{*}{$\begin{array}{l}\text { Types of } \\
\text { respondents }\end{array}$} & \multirow[t]{2}{*}{$\mathbf{N}$} & \multicolumn{2}{|c|}{ Gender } & \multicolumn{2}{|c|}{ Residential } & \multicolumn{4}{|c|}{ Educational Aspiration } & \multicolumn{2}{|c|}{$\begin{array}{c}\text { Whose } \\
\text { decision: } \\
\text { quit/not quit? }\end{array}$} \\
\hline & & $F$ & $M$ & Urban & Suburb & $H S$ & $B A$ & $M A$ & $P h D$ & Parents & Own \\
\hline N-EPT & 4 & 2 & 2 & 3 & 1 & $\begin{array}{c}1 \\
(F=1)\end{array}$ & - & $\begin{array}{c}2 \\
(F=1)\end{array}$ & 1 & $\begin{array}{c}3 \\
(F=2) \\
\end{array}$ & 1 \\
\hline EPT & 4 & 3 & 1 & 2 & 2 & - & - & $\begin{array}{c}2 \\
(F=2)\end{array}$ & $\begin{array}{c}2 \\
(F=1)\end{array}$ & $\begin{array}{l}2 * \text { but } \\
\text { ignored }\end{array}$ & $\begin{array}{c}2 \\
(F=1) \\
\end{array}$ \\
\hline
\end{tabular}

Three main themes could be formed to respond as to why the students decided to follow their choice, EPT or N-EPT, in this study like benefits in the exam, the matter of time, the matter of teachers. First, quit or stay in EPT does not have an association with any types of examination or academic achievement in this study. However, students accepted the fact that it will be beneficial to them if they are able to score better in English examination. Regardless of respondent types, all of them correctly understood in what way English can or cannot affect their exam results. Although this surplus value sounds excellent or helpful to them, none of them tend to express it as their interest or to view it as a tool to motivate them to invest in it. Furthermore, $62.5 \%$ argued that they could manage to pass the English examination due to its low level of difficulty. However, $37.5 \%$ voiced out that they are not confident regarding their English capacity even if many of them were in EPT when they were asked: "Do you think you can obtain the surplus-value from English examination in your national exam?”

"We know [and were told] that English doesn't harm our results [of national exam], but it will help if we can do it better [secure more than 25 out of 50]. Yet, I think I am able to deal with it because it is simple, as I know. [....] I saw the previous years' English tests. They are not so difficult because it is like the English for Cambodia ${ }^{2}$. [it is easy]" EPT3

“[....] I am not sure if I can do it well. I only study general English [to improve four macro skills, including grammar] at my private tutoring class like Headway

\footnotetext{
2. It is the textbook used in Cambodian schools. There are six separate books. One of which is used for one grade, like English for Cambodia Book One (EfC1) for seventh grade, EfC2 is for eighth grade, etc.
} 
and TopNotch [book], I am not studying for this [national] exam. But it is okay because [English subject] does not influence [my] result" EPT1

Second, the prime factors impacting on the students' choice 'to quit' are requiring time for core exam subject PT and parents' influence on their decision making. However, similar to Chan's study (2018) in the same context, the students in the present study admitted that English is vital for their future success including education and career. Interestingly, some of the EPT group decided to disregard parents' requests and to continue following EPT. Yet, it was found that the N-EPT group thought they will resume EPT after the national exam. This finding is consistent with the reasons shown in Table 3. In addition to this, succeeding in the national exam means everything to both EPT and N-EPT groups, and it is given the highest priority.

“ [....] without good knowledge [of English], we will face many challenges in our future lives [study and career]. My parents asked me to stop English private class to study Mathematics [private] class, [parents] told me I can learn it [English] after the exam. I agreed to them because BacII [High School certificate] is everything for my life. Without it, I cannot do anything. I must prioritize it." NEPT2

"[...] time for Biology [private] class overlaps my English class, so I dropped it [English] because I do not have any time left if I do not quit English. [...] my parents do not care about it, it is my future, so I have to do what I can to pass this BacII certificate. [...] English is my last priority for me." N-EPT4

"[....] if I still have time, I will learn it [English]. But I will quit it for some time for Khmer [literature and composition] before the exam." EPT2

Last, English teachers' absenteeism and focusing only on grammar are what drive students to look for EPT because they felt that this would not help to improve their English. They felt like learning only grammar will not help them achieve their needs in English but may help them to some extent in preparing for the exam. This is aligned with Yung's (2015) findings of EPT in Hong Kong, where the focus is on preparing students for the examination but not helping them improve their English communication competencies.

"[we] won't learn anything if we do not go to the supplementary class of English. As you [interviewer] may know, the contents in the textbook are outdated. Teachers miss class so often. When [they] come, they teach only grammar and 
ask us to do the exercises in the book. To me, it is not what I want because English is not used only for an exam in my life." EPT4

“[...] I could not improve my English at my [mainstream] school. Of course, I learned some grammar and structure, or I can revise whatever I have learned in EPT for the exam. But if we want more than this [learn for exam], we have to learn outside [of mainstream school]." N-EPT2

Again, this mixed-method study indicates that SES plays a vital part in influencing the decision to quit or continue EPT among the Cambodian $12^{\text {th }}$ graders. Although students who are from better income families quit EPT, this decision is primarily influenced by their parents and the time overlap to follow the core exam subjects PT. In addition to this, although this study did not attempt to evaluate the core exam subject PT, its result inevitably explained that majorities of parents prioritize those subjects rather than any elective subject like English that may not affect the national exam of their children. Similarly, some students will give up EPT if they cannot manage their time for the core exam subjects. Predictively, Cambodian $12^{\text {th }}$ graders tend to classify the exam subjects into three levels of priority. The first level comprises Mathematics, Biology, Chemistry and Physics, while in the second level there are Khmer literature and composition as well as History. The final level consists of languages (English and French), which are electives. Nonetheless, those who are able to manage their time are keen to stay with EPT even though English is their last priority. They felt that they need English not only to secure part-time employment in the short run but also for future success. Besides, students who have higher educational aspirations and internal motivation will undoubtedly stay with EPT, although they all agree that BacII (High School) certificate is priceless for them.

Qualitatively, absenteeism of teachers is found as a factor urging students to take EPT. Though this variable is not statistically significant in the last regression model, its trend is consistent with the qualitative data. Teacher absenteeism surely causes the loss of instructional time, so with this insufficient instructional time, students require supplementary tutoring (Kobakhidze, 2015) not only for core exam subjects but also for English. Also, 
in late 2018, local news, Khleykhley ${ }^{3}$, reported the speech of HangChuon Narong, Minister of MoEYS, denouncing that 'loss of instructional time' and 'lack of teaching quality' are the two pronounced causes of Cambodian students' low achievement in PISA-D.

Unlike the previous study, this study makes the blurring reasons between N-EPT and EPT clear. Time management issues, requests from parents to quit EPT, and assumptions about the low level of difficulty of English tests contributed towards $12^{\text {th }}$ graders opting out of EPT. On the other hand, some do their best to stay in EPT even if the final aim is not to better the achievement in the national exam. They think of its usefulness in the long run for securing part-time employment as well as for their future success. However, concerns about obtaining the surplus-value were raised due to a lack of exam preparation at EPT. Therefore, this finding shed light on how ESL/EFL practitioners and English syllabus writers can support their students in maintaining a balance between succeeding in the exam as well as in their career by integrating both exam skills and communicative skills. If the 'exam-career balance' syllabus is put into practice, this may boost the $12^{\text {th }}$ graders' commitment towards studying English in both mainstream classes and EPT.

Dawson (2010, p. 15) argued that PT might be functioning as a 'parasitic' instead of a 'symbiotic' system. In the 'parasitic' system, PT exploits benefits from the mainstream system and can also harm the mainstream teaching and learning quality, unlike in the 'symbiotic' system. The above argument can be linked to the view that when English is 'just' a subject for the exam, the private tutoring of that kind of subject may be functioning as a 'parasitic system' rather than a 'symbiotic system.' However, it is worth highlighting that EPT is still in demand in Cambodia due to Cambodian's strong perceptions towards English as a language contributing to better their lifestyle (Keuk, 2009), a passport to facilitate overseas study and secure a better job (Igawa, 2010), as well as a visa to work and travel in ASEAN countries (Chan, 2018).

\footnotetext{
${ }^{3}$ https://kleykley.sabay.com.kh/article/1110135?fbclid=IwAR0O5qjmrKK1_ul-En-_wR0cHxWtV7eq1fKrvAd1eqiU0sRkeDOe_v_Ws8 (retrieved in December 2018)
} 
338 TEFLIN Journal, Volume 31, Number 2, July 2020

\section{CONCLUSIONS}

EPT is popular among Cambodian students and has been attracting more attention from Cambodian $12^{\text {th }}$ graders despite not being a 'core' exam subject. No correlation has been found between reasons to follow EPT and its impact on surplus value in this study. Those who decided to continue EPT at this grade seem to be motivated by their future needs. Some of them required English not only to succeed in future academic life but also to secure part-time employment to support themselves during their university life. Inevitably, EPT students face harder times than their counterparts because they need to focus on both their core exam subjects as well as develop their English proficiency. However, they do not receive any exam preparations from EPT, which could help them obtain surplus value in their national exam due to a lack of attention from EPT suppliers.

This study suggests that integrating exam skills along with English proficiency will be a contributing factor towards the success of Cambodian $12^{\text {th }}$ graders in both their national exam and future. Therefore, an 'exam-career balance' syllabus should be developed and implemented in both mainstream and private classes/schools as it will be useful to both EPT and N-EPT students. Furthermore, it is suggested that ESL/EFL researchers integrate more variables from schools as well as investigate parents' and teachers' perceptions and attitudes towards EPT so as to contextualize and implement this syllabus better.

\section{ACKNOWLEDGMENT}

The author appreciates his four assistants for their unconditional support throughout the data collection process, and his anonymous reviewers for their constructive comments.

\section{REFERENCES}

Bray, M. (1999). The private costs of public schooling: Household and community financing of private education in Cambodia. UNESCO International Institute for Educational Planning (IIEP). 
Bray, M. (2008). Double-shift schooling: Design and operation for costeffectiveness. UNESCO International Institute for Educational Planning (IIEP).

Bray, M. (2010). Blurring boundaries: The growing visibility, evolving forms and complex implications of private supplementary tutoring. ORBIS SCHOLAE, 4(2), 61-73.

Bray, M. (2013). Shadow education: Comparative perspectives on the expansion and implications of private supplementary tutoring. ProcediaSocial and Behavioral Sciences, 77, 412-420.

Bray, M., \& Kwo, O. (2014). Regulating private tutoring for public good: Policy options for supplementary education in Asia. UNESCO Comparative Education Research Center (CERC), The University of Hong Kong.

Bray, M., Kwo, O., \& Jokic, B. (2015). Introduction. In M. Bray, O. Kwo, \& B. Jokic, Researching private supplementary tutoring: Methodological lesson from diverse cultures (pp. 3-19). Springer \& Comparative Education Research Center (CERC), The University of Hong Kong.

Chan, H. (2018). Cambodian EFL students' investment in learning English: Perspectives and practices. TEFLIN Journal, 29(1), 45-71.

Chao, X., Xue, M., \& Xu, M. (2014). Elementary English education: An arena of social struggle for professional Chinese parents. Critical Inquiry in Language Studies, 11(4), 252-272.

Clayton, T. (2007). Transition, culure, and language in Cambodia. In A. B. Tsui, \& J. W. Tollefson, Language Policy, Culture, and Identity in Asian Contexts (pp. 95-120). Lawrence Erlbaum Associates.

Coniam, D. (2014). How much do students benefit from attending private tutorial schools? A case study of the Hong Kong shadow education system. In D. Coniam (Ed.), English language education and assessment: Recent developments in Hong Kong and the Chinese mainland (pp. 103119). Springer.

Creswell, J. W., \& Plano Clark, V. L. (2017). Designing and conducting mixed methods research (3rd ed.). Sage.

Dang, H.-A. H. (2013). Private tutoring in Vietnam: A review of current issues and its major correlates. The World Bank Development Research Group: Poverty and Inequality Team. 
Dawson, W. (2010). Private tutoring and mass schooling in East Asia: Reflections of inequality in Japan, South Korea, and Cambodia. Asia Pacific Education Review, 11, 14-24.

Dornyei, Z., \& Chan, L. (2013). Motivation and vision: An analysis of future L2 self image, sensory styles, and imagery capacity across two target langauges. Language Learning, 63(3), 437-462.

Hamid, M., Khan, A., \& Islam, M. (2018). The spread of private tutoring in English in developing societies: Exploring students' perceptions. Discourse: Studies in the Cultural Politics of Education, 39(6), 868-886.

Hamid, M., Sussex, R., \& Khan, A. (2009). Private tutoring in English for secondary school students in Bangladesh. TESOL QUARTERLY, 43(2), 281-308.

Hamind, M. (2016). The linguistic market for English in Bangladesh. Current Issues in Language Planning, 17(1), 36-55.

Huang, H.-T. (2017). Private English tutoring and adolescents' motivation to learn English as a foreign language: A self system perspective. Taiwan Journal of TESOL, 14(1), 1-36.

Igawa, K. (2010). The impact of English language education on Cambodian elementary school children: Perceptions of EFL teachers in Cambodia. Shitennoji University Bulletin, 147-165.

Keuk, C. N. (2009). How intelligible is Cambodian English variety? A look from foreigners' perspectives. CamTESOL Conference on English Langugae Teaching: Selected Papers, 5, 23-35.

Kobakhidze, M. N. (2015). Shadow education research through TIMSS and PIRLS: Experiences and lessons in the Republic of Georgia. In M. Bray, O. Kwo, \& B. Jokic, Researching private supplementary tutoring: Methodological lessons from diverse cultures (pp. 23-48). Springer \& Comparative Education Research Center (CERC), The University of Hong Kong.

Kwok, P. L. (2010). Demand intensity, market parameters and policy responses towards demand and supply of private supplementary tutoring in China. Asia Pacific Education Review, 11(1), 49-58.

Lee, B. (2010). The pre-university English-educational background of college freshmen in a foreign language program: A tale of diverse private education and English proficiency. Asia Pacific Education Review, 11, 6982. 
Leech, B. (2002). Asking questions: Techniques for semistructured interview. PS: Political Science and Politics, 35(4), 665-668.

Mahmud, R., \& Bray, M. (2017). School factors underlying demand for private supplementary tutoring in English: Urban and rural variations in Bangladesh. Asia Pacific Journal of Education, 1-11.

Mahmud, R., \& Kenayathulla, H. B. (2018). Shadow education: Patterns and scale of private supplementary tutoring in English in secondary education at urban Dhaka in Bangladesh. Compare: A Journal of Comparative and International Education, 48(5), 702-716.

MoEYS. (2005). Including English and French in $12^{\text {th }}$ grade's national examination for academic year 2005-2006 ( $\mathrm{N}^{\circ} .1877$ moeys.m.ch.t). MoEYS. (in Khmer)

Neau, V. (2003). The teaching of foreign languages in Cambodia: A historical perspective. Language, Culture, and Curriculum, 16(3), 253-268.

Niu, L. (2017). Family socioeconomic status and choice of STEM major in college: An analysis of a national sample. College Student Journal, 5(12), 298-312.

Prak, H., Byun, S.-y., \& Kim, K.-k. (2011). Parental involvement and students' cognitive outcomes in Korea: Focusing on private tutoring. Sociology of Education, 84(1), 3-22.

Valerio, A. (2013). Private tutoring in modern times. Is it really effective? Procedia-Social and Behavioral Sciences, 70, 979-985.

William, B. C., \& Silova, I. (2014). Hidden privatization of public education in Cambodia: Equity implications of private tutoring. Journal for Educational Research Online, 6(1), 94-116.

Yung, K. W.-H. (2015). Learning English in the shadow: Understanding Chinese learners' experiences of private tutoring. TESOL QUARTERLY, 49(4), 707-732.

Zhao, L. (2012). Investigation into motivation types and influence on motivation: The case of Chinese non-English majors. English Language Teaching, 5(3), 100-122. 